Fikroh : Jurnal Pemikiran dan Pendidikan Islam

Volume. 13, Number. 1, Januari 2020

p-ISSN : 2087-7501, e-ISSN : 2715-4459

H1m : 1-16

Journal Home Page : https://jurnal.stai-alazharmenganti.ac.id/index.php/fikroh

\title{
MOVIE THERAPY TO DEVELOPING PROSOCIAL BEHAVIOR OF CHILDHOODS
}

\author{
Dian Renata \\ Universitas Indraprasta PGRI, Jakarta, Indonesia \\ renadhi83@gmail.com \\ Hengki Satrianta \\ Universitas Indraprasta PGRI, Jakarta, Indonesia \\ hengkibk12@gmail.com \\ Rezky Permatasari \\ Universitas Indraprasta PGRI, Jakarta, Indonesia \\ rezky1023@gmail.com \\ Anna Rufaidah \\ Universitas Indraprasta PGRI, Jakarta, Indonesia \\ annarufaidah86@gmail.com \\ Sri Utami \\ Universitas Indraprasta PGRI, Jakarta, Indonesia \\ sriutami.unindra@gmail.com \\ Afiatin Nisa \\ Universitas Indraprasta PGRI, Jakarta, Indonesia \\ afiatinnisa83918@gmail.com
}

\begin{abstract}
Movie therapy to developing prosocial behavior of childhoods. The phase of human life was beginning from the prenatal period and will end in late adulthood. Childhoods is critical age or golden age. In this phase childs tend to be selfish and far form prosocial behavior. This was need to be given intervention. One of intervention than can given through movie therapy. This article aim to describe whether movie therapy can develop prosocial behavior of childhoods. This research used quantitative research with experiment method. Samples in this research
\end{abstract}




\title{
Dian R., Hengki S., Rezky P., Anna R., Sri Utami, dan Afiatin Nisa
}

was 17 students. Instrument of this research was used prosocial behavior scale. Data were analyzed by sign test. The result shown that movie therapy was able to develop childhoods prosocial behavior. Implications of this findings in teacher and especially school counselors must to try this method to help childhoods with the lack of prosocial behavior. So, happy watching!

Keywords: movie therapy; prosocial behavior

\begin{abstract}
Abstrak
Tahap kehidupan manusia dimulai dari periode pranatal dan berakhir pada masa usia lanjut. Masa usia dini merupakan usia kritis atau biasa pula disebut usia emas. Pada fase ini ada kecenderungan anak menjadi egois dan tidak berperilaku prososial. Hal ini tentu membutuhkan penanganan. Salah satu upaya penanganan yang dapat dilakukan adalah melalui movie therapy. Artikel ini menjelaskan apakah movie therapy mampu mengembangkan perilaku prososial pada anak usia dini. Penelitian ini adalah penelitian kuantitatif dengan jenis eksperimen. Sampel dalam penelitian ini berjumlah 17 siswa. Instrumen yang digunakan dalam penelitian ini adalah skala perilaku prososial. Data dianalisis dengan menggunakan uji tanda. Hasil penelitian ini menunjukkan bahwa movie therapy mampu meningkatkan perilaku prososial pada anak usia dini. Implikasi dari hasil penelitian ini adalah guru dan secara khusus konselor sekolah perlu mencoba metode ini untuk membantu siswa yang kurang memiliki perilaku prososial. Selamat menonton!
\end{abstract}

Kata kunci: movie therapy; perilaku prososial

\section{A. Pendahuluan}

Fase kehidupan manusia dimulai saat memasuki masa prenatal dan akan berakhir pada masa dewasa akhir. Fase kehidupan yang terjadi akan berlangsung dengan tugas yang sederhana menuju ke tugas-tugas yang sifatnya lebih kompleks. Salah satu bentuk perkembangan yang terjadi pada manusia adalah perkembangan sosial emosi. Perkembangan sosial emosi merupakan salah satu bentuk perkembangan yang perlu mendapat perhatian khusus di samping perkembangan lainnya. Khusus pada anak usia dini, perkembangan sosial emosi dinyatakan sebagai sebuah krisis. ${ }^{1}$ Jika pada masa ini tidak dapat dioptimalkan pada diri invidividu maka akan mengganggu perkembangan pada tahap-tahap selanjutnya. ${ }^{2}$ Usia dini disebut sebagai tahapan kritis atau golden age. ${ }^{3}$

\footnotetext{
1 Femmi Nurmalitasari, "Perkembangan Sosial Emosi Pada Anak Usia Prasekolah," Buletin Psikologi, (2015), https://doi.org/10.22146/bpsi.10567.

2 R.D. Briggs, "The Importance of Social Emotional Development in Early Childhood,” Pediatrics for Parent 28 (2012): $10-16$.

${ }^{3}$ Nurmalitasari, "Perkembangan Sosial Emosi Pada Anak Usia Prasekolah."
} 
Pada tahap ini individu telah berfungsi sebagian besar jaringan sel-sel pada otaknya yang merupakan pengendali setiap aktivitas manusia. Anak usia dini adalah seorang anak yang usianya belum memasuki suatu lembaga pendidikan formal seperti Sekolah Dasar (SD) dan biasanya mereka tetap tinggal di rumah atau mengikuti kegiatan dalam bentuk berbagai lembaga pendidikan prasekolah, seperti kelompok bermain, taman kanak-kanak, atau taman penitipan anak. Pada masa ini anak mulai mengembangkan kemampuan motorik indrawi, visual dan auditori yang distimulasi melalui lingkungan sekitarnya. ${ }^{4}$ Dibutuhkannya lingkungan dalam menstimulasi anak usia dini tidak terlepas dari fakta bahwa semua orang membutuhkan orang lain. ${ }^{5}$ Manusia, termasuk anak usia dini adalah makhluk individu dan makhluk sosial. Sebagai makhluk sosial anak usia dini diharapkan mampu melakukan berbagai perilaku sosial yang bersifat sederhana, salah satunya perilaku menolong.

Perilaku menolong manusia yang dilakukan tanpa pamrih dan tidak mengandung maksud tertentu secara umum dikenal dengan perilaku prososial. Perilaku prososial merupakan sejumlah tindakan yang dilakukan untuk memberikan keuntungan kepada orang lain, seperti berbagi dengan orang yang kekurangan, membuat nyaman atau menyelematkan seseorang, atau secara sederhana membuat perasaan orang lain menjadi baik dengan memberi salam atau pujian. ${ }^{6}$ Perilaku prososial dimulai dan tumbuh sejak dua tahun pertama kehidupan. ${ }^{7}$ Pada masa bayi yang berusia 12 sampai 24 bulan perilaku prososial ditunjukkan dengan kesanggupan membantu, merasa nyaman, berbagi, dan bekerja sama dengan yang lain. ${ }^{8}$ Hal tersebut akan semakin berkembang dengan seiring bertambahnya usia. Nilai-nilai prososial pada seseorang didasarkan pada nilai etika, moral dan adat-istiadat semestinya menciptakan keharmonisan pada lingkungan yang ditempati anak usia dini.

\footnotetext{
4 D.H. Schunk, Learning Theories An Educational Perspective Teori-Teori Pembelajaran: Perspektif Pendidikan, 6th ed. (Yogyakarta: Pustaka Pelajar, 2012).

5 Prayitno and Erman Amti, Dasar-Dasar Bimbingan Dan Konseling, Edisi Revi (Jakarta: PT. Rineka Cipta, 2013).

${ }^{6}$ David R Shaffer and K. Kipp, Developmental Psychology: Childhood and Adolescence, 8th ed. (Belmont, CA 94002- 3098: Wadsworth, 2010).

${ }^{7}$ Celia A. Brownell, "Early Development of Prosocial Behavior: Current Perspectives," Infancy 18, no. 1 (2013): 1-9, https://doi.org/10.1111/infa.12004;

8 Joscha Kärtner, Heidi Keller, and Nandita Chaudhary, "Cognitive and Social Influences on Early Prosocial Behavior in Two Sociocultural Contexts.," Developmental Psychology 46, no. 4 (2010): 905-14, https://doi.org/10.1037/a0019718.
} 


\section{Dian R., Hengki S., Rezky P., Anna R., Sri Utami, dan Afiatin Nisa}

Namun pada kenyataannya, nilai-nilai prososial yang ada pada anak usia dini menunjukkan adanya perkembangan yang kurang optimal. Ketidakoptimalan perkembangan perilaku prososial ditunjukkan dengan perilaku egois, menang sendiri, mengatur teman, bertengkar, kekerasan fisik serta psikis. ${ }^{9}$ Alasan utama timbulnya ketidakoptimalan tersebut terletak pada egosentrisme pada anak usia dini ${ }^{10}$ serta status sosial. ${ }^{11}$

Egosentrisme disebabkan oleh ketidakpahaman anak dalam memahami sudut pandang pemikiran orang lain. Anak belum mengerti bahwa lingkungan memiliki cara pandang yang berbeda dengan dirinya. ${ }^{12}$ Hal ini mengakibatkan anak hanya mengutamakan dirinya saja. Untuk itu dilakukan observasi untuk melihat bagaimana perilaku prososial pada anak usia dini, dalam hal ini pada anak SD. Observasi dilakukan pada awal September di salah satu SD di wilayah Jakarta Timur. Berdasarkan hasil observasi ditemukan gejala rendahnya perilaku prososial pada siswa diantaranya kurangnya kesadaran dalam memperhatikan keadaan teman sekelas, rendahnya kesadaran untuk mengatur bangku kelas atau membersihkan papan tulis.

Selain itu ditemukan pula siswa yang melakukan perundungan, tidak peduli pada teman yang tidak memiliki uang, memanggil temannya dengan sebutan kasar, enggan berbagi, kurang peduli pada teman, dan sejenisnya. Hal ini tentunya membutuhkan penanganan khusus dalam upaya meningkatkan perilaku prososial pada anak usia dini. Ada banyak upaya yang dapat dilakukan dalam rangka meningkatkan perilaku prososial, misalnya melalui permainan, ${ }^{13}$ program media elektronik, ${ }^{14}$ sinkroni interpersonal, ${ }^{15}$ bermain

\footnotetext{
9 Kadek Suranata and Made Sulastri, "Masalah-Masalah Yang Dialami Anak Usia Dini Dan Implikasinya Bagi Pelaksanaan Bimbingan Dan Konseling di Taman Kanak-Kanak," Jurnal Pendidikan Dan Pengajaran XLIII, no. 11 (2010): 89-95.

${ }^{10}$ S. Suyanto, Dasar-Dasar Pendidikan Anak Usia Dini (Yogyakarta: Hikayat Publishing, 2005).

11 Ana Guinote et al., "Social Status Modulates Prosocial Behavior and Egalitarianism in Preschool Children and Adults," Proceedings of the National Academy of Sciences 112, no. 3 (2015): 731-36, https://doi.org/10.1073/pnas.1414550112.

12 Suyanto, Dasar-Dasar Pendidikan Anak Usia Dini.

${ }^{13}$ Deborah M. Plummer, Helping Children to Improve Their Communication Skills: Therapeutic Activities for Teachers and Parents and Therapists (London \& Philadelphia: Jessica Kingsley Publishers, 2011), https://doi.org/10.1080/1034912X.2014.934022.

14 J.W Santrock, Child Development, Climate Change 2013-The Physical Science Basis, 13th ed. (New York: McGraw-Hill Companies, Inc., 2010), https://doi.org/10.1017/CBO9781107415324.004.

15 Laura K. Cirelli, Kathleen M. Einarson, and Laurel J. Trainor, "Interpersonal Synchrony Increases Prosocial Behavior in Infants,” Developmental Science 17, no. 6 (2014): 1003-11, https://doi.org/10.1111/desc.12193.
} 
musik bersama, ${ }^{16}$ penerimaan teman sebaya, ${ }^{17}$ nostalgia, ${ }^{18}$ program Root of Empathy ROE), ${ }^{19}$ kurikulum berbasis keramahan, ${ }^{20}$ video games, ${ }^{21}$ cerita sosial, ${ }^{22}$ dan movie therapy ${ }^{23}$.

Upaya-upaya tersebut di atas pada prinsipnya merupakan hal baik dan dapat dilakukan. Akan tetapi dari sekian banyak bentuk intervensi yang diajukan maka penulis tertarik untuk meningkatkan perilaku prososial melalui movie therapy. Berdasarkan penjelasan-penjelasan di atas maka masalah dalam penelitian ini adalah apakah movie therapy mampu mengembangkan perilaku prososial pada anak usia dini? Movie therapy adalah teknik terapeutik yang melibatkan pemilihan dan penugasan film yang cermat untuk ditonton oleh para klien, diikuti dengan pengolahan pengalaman mereka selama sesi terapi bersamaan dengan karakter utama dalam film ${ }^{25}$. Istilah movie therapy sering disebut dengan cinematherapy, film therapy dan reel therapy. Movie therapy sebagai teknik terapi di dalamnya menggunakan film komersial yang dipilih untuk mendapatkan arti terapeutik pada klien tentang pandangan terhadap individu atau terhadap orang lain.

Film menyajikan potensi kekuatan baru untuk menerangi kedalaman pengalaman manusia. Movie therapy membuat kekuatan itu sebagai alat untuk meningkatkan kesadaran. Melalui movie therapy, klien akan belajar dalammencari dan menemukan suatu wawasan

16 S. Kirschner Sebastian and Michael Tomasello, "Joint Music Making Promotes Prosocial Behavior in 4- Year-Old Children," Evolution and Human Behavior 31, no. 5 (2010): 354-64, https://doi.org/10.1016/j.evolhumbehav.2010.04.004.

${ }^{17}$ Kristin Layous et al., "Kindness Counts: Prompting Prosocial Behavior in Preadolescents Boosts Peer Acceptance and Well-Being," PLoS ONE 7, no. 12 (2012): 7-9, https://doi.org/10.1371/journal.pone.0051380.

18 Arber Tasimi and Liane Young, "Memories of Good Deeds Past: The Reinforcing Power of Prosocial Behavior in Children," Journal of Experimental Child Psychology 147 (2016): 159-66, https://doi.org/10.1016/j.jecp.2016.03.001; Ya Li, "Nostalgia Promoting Pro-Social Behavior and Its Psychological Mechanism," Open Journal of Social Sciences 3, no. October (2015): 177-86.

${ }^{19}$ Kimberly A. Schonert-Reichl et al., "Promoting Children's Prosocial Behaviors in School: Impact of the 'Roots of Empathy' Program on the Social and Emotional Competence of School-Aged Children," School Mental Health 4, no. 1 (2012): 1-21, https://doi.org/10.1007/s12310-011-9064-7.

${ }^{20}$ Lisa Flook et al., "Promoting Prosocial Behavior and Self-Regulatory Skills in Preschool Children through a Mindfulness-Based Kindness Curriculum.," Developmental Psychology 51, no. 1 (2015): 44-51, https://doi.org/10.1037/a0038256.

21 Tobias Greitemeyer and Silvia Osswald, "Effects of Prosocial Video Games on Prosocial Behavior.," Journal of Personality and Social Psychology 98, no. 2 (2010): 211-21, https://doi.org/10.1037/a0016997.

${ }^{22}$ Lisa A. Wright and Rebecca B. McCathren, "Utilizing Social Stories to Increase Prosocial Behavior and Reduce Problem Behavior in Young Children with Autism," Child Development Research 2012 (2012): 1-13, https://doi.org/10.1155/2012/357291.

23 Douglas A. Gentile et al., "The Effects of Prosocial Video Games on Prosocial Behaviors: International Evidence From Correlational, Longitudinal, and Experimental Studies," Personality and Social Psychology Bulletin 35, no. 6 (2009): 752-63, https://doi.org/10.1177/0146167209333045. 


\section{Dian R., Hengki S., Rezky P., Anna R., Sri Utami, dan Afiatin Nisa}

baru dalam memandang fenomena sosial yang terjadi di lingkungan sekitarnya berdasarkan hasil tontonannya sendiri. Pertimbangan penggunaan movie therapy didasarkan pada kenyataan bahwa anak usia dini senang menonton film. Bahkan dari awal kehidupan, dunia bayi dan anak kecil tertanam di media layar, termasuk media interaktif digital yang salah satunya adalah tayangan televisi seperti film. ${ }^{24}$ Film sebagai media pembelajaran artinya alat yang dapat dilihat dan didengar yang dipakai dalam proses pembelajaran dengan maksud untuk membuat cara berkomunikasi lebih efektif dan efisien. ${ }^{25}$

Film termasuk ke dalam kategori audio visual yang menyajikan tampilan gambar gerak dan suara, gambar gerak digunakan untuk merangsang penonton melalui indera penglihatan dan suara digunakan untuk merangsang penonton melalui indera pendengaran. Penggabungan indera penglihatan dan pendengaran diharapkan menjadikan penonton lebih mudah menyerap informasi yang diberikan. Para ahli juga memilki pandangan yang sama akan hal itu, perolehan hasil belajar melalui indera penglihatan dan indera pendengar sangat menonjol perbedaannya.

Menurut Baugh, kurang lebih 90\% hasil belajar seseorang diperoleh melalui indera pandang, hanya 5\% diperoleh melalui indera pendengaran dan 5\% lagi dengan indera lainnya. ${ }^{26}$ Selain itu, film dibuat dengan tujuan utama untuk menghibur, tetapi kini film dibuat untuk meningkatkan kesehatan perilaku individu. ${ }^{27}$ Selanjutnya, alasan lain pemilihan movie therapy terletak dari kelebihan film dibandingkan dengan media yang lain, yakni: a) Pesan akan memperoleh tanggapan yang lebih jelas dan tidak mudah dilupakan, karena antara melihat dan mendengar dapat dikombinasikan menjadi satu, b) Dapat menikmati kejadian dalam waktu yang lama pada suatu proses atau peristiwa tertentu, c) Dengan teknik slow-motion dapat mengikuti suatu gerakan atau aktivitas yang berlangsung cepat, d) Dapat mengatasi keterbatasan ruang dan waktu, e) Dapat membangun sikap, perbuatan dan

\footnotetext{
${ }^{24}$ Molaie and Abedin, "Effectiveness of Group Movie Therapy (GMT) on Reduction of Grief Experience Intensity in Bereaved Adolescent Girls."

${ }^{25}$ Sarah L. Calvert, "Media and Early Development," in Blackwell Handbook of Early Childhood Development, ed. Kathleen McCartney and Deborah Phillips (UK: Blackwell Publishing, 2006), 508-30, https://doi.org/10.1007/s13398-014-0173-7.2.

26 E Nurjanah, "Pengaruh Media Film Terhadap Motivasi Belajar Dalam Pembelajaran Pendidikan Kewarganegaraan (PKn)" (University of Education Indonesia, 2013).

${ }^{27}$ Yazici et al., "Use of Movies for Group Therapy of Psychiatric Inpatients: Theory and Practice."
} 
membangkitkan emosi dan mengembangkan problema. ${ }^{28}$ Film tidak diharapkan bermakna tunggal, melainkan dapat dipertimbangkan sebagai suplemen dalam cara berpikir tentang dunia. $^{29}$ Lebih jauh, film menyangkut emosi, yang kekuatannya berkaitan dengan keseimbangan psikis individu. Berdasarkan uraian-uraian di atas maka hipotesis penelitian ini adalah movie therapy mampu mengembangkan perilaku prososial pada anak usia dini.

\section{A. Metode Penelitian}

Penelitian ini dijalankan dengan menggunakan pendekatan kuantitatif. Variabel dalam penelitian ini yakni movie therapy sebagai variabel bebas dan perilaku prososial sebagai variabel terikat. Jenis penelitian yang digunakan adalah eksperimen dengan jenis one group pretest-posttest control group design. ${ }^{30}$ Populasi dalam penelitian ini adalah siswa Sekolah Dasar yang terletak di Jakarta Timur dengan jumlah 59 siswa. Sampel dalam penelitian ini ditarik dengan menggunakan teknik purposive sampling. Berdasarkan studi pendahuluan diketahui bahwa terdapat 17 siswa yang mengalami perilaku prososial rendah sehingga sampel berjumlah 17 siswa. Penelitian ini dilakukan sebanyak enam kali pertemuan dengan empat kali pelaksanaan movie therapy disertai dengan pretest dan posttest. Data diperoleh dari instrumen skala perilaku prososial yang dikonstruksi berdasarkan pendapat Brownell. ${ }^{31}$ Data dianalisis dengan menggunakan uji tanda (sign test) dengan bantuan program SPSS versi 20.

\section{B. Hasil dan Pembahasan}

Penelitian ini dilakukan sebanyak enam kali pertemuan dengan rincian pertemuan pertama pretest, pertemuan kedua pelaksanaan movie therapy I: Bidadari-Bidadari Surga, pertemuan ketiga pelaksanaan movie therapy II: Kung Fu Panda II, pertemuan keempat pelaksanaan movie therapy III: Lima Elang, pertemuan kelima pelaksanaan movie therapy IV:

\footnotetext{
28 Nurjanah, "Pengaruh Media Film Terhadap Motivasi Belajar Dalam Pembelajaran Pendidikan Kewarganegaraan (PKn)."

${ }^{29}$ Carla Gramaglia et al., "Cinema in the Training of Psychiatry Residents: Focus on Helping Relationships.," BMC Medical Education 13, no. 1 (2013): 90, https://doi.org/10.1186/1472-6920-13-90.

30 A.Muri Yusuf, Metode Penelitian: Kuantitatif, Kualitatif, Dan Penelitian Gabungan (Jakarta: Kencana Prenadamedia Group, 2014).

31 Brownell, "Early Development of Prosocial Behavior: Current Perspectives."
} 


\section{Dian R., Hengki S., Rezky P., Anna R., Sri Utami, dan Afiatin Nisa}

Sang Pemimpi, dan pertemuan keenam merupakan tahap posttest. Berikut merupakan hasil pretest pada 17 sampel penelitian.

Tabel 1. Deskripsi pretest sampel penelitian

\begin{tabular}{|c|c|c|c|}
\hline Interval & Kategorisasi & Frekuensi & Persentase $(\%)$ \\
\hline$\geq 113$ & Sangat Tinggi & 0 & 0 \\
\hline $98-112$ & Tinggi & 0 & 0 \\
\hline $83-97$ & Sedang & 3 & 17,65 \\
\hline $68-82$ & Rendah & 10 & 58,82 \\
\hline$<67$ & Sangat Rendah & 4 & 23,53 \\
\hline \multicolumn{2}{|c|}{ Jumlah } & 17 & 100 \\
\hline
\end{tabular}

Berdasarkan tabel 1 diketahui bahwa tidak terdapat siswa (0\%) yang tingkat perilaku prososialnya pada kategori sangat tinggi dan tinggi, terdapat tiga siswa (17,65\%) yang tingkat perilaku prososialnya pada kategori sedang, 10 siswa (58,82\%) memiliki tingkat perilaku prososial pada kategori rendah, serta empat siswa $(23,53 \%)$ dengan tingkat perilaku prososial yang sangat rendah. Hasil ini menggambarkan bahwa tingkat perilaku prososial siswa sebelum diberikan movie therapy berada pada kategori rendah. Siswa kemudian diberikan movie therapy berdasarkan langkah-langkah yang telah ditetapkan. Setelah diberikan movie therapy sebanyak empat sesi, di pertemuan keenam dilakukan posttest dengan sebagaimana disajikan pada tabel 2 berikut.

Tabel 2. Deskripsi posttest sampel penelitian

\begin{tabular}{|c|c|c|c|}
\hline Interval & Kategorisasi & Frekuensi & Persentase $(\%)$ \\
\hline$\geq 113$ & Sangat Tinggi & 2 & 11,76 \\
\hline $98-112$ & Tinggi & 9 & 52,94 \\
\hline $83-97$ & Sedang & 2 & 11,76 \\
\hline $68-82$ & Rendah & 3 & 17,65 \\
\hline$<67$ & Sangat Rendah & 1 & 5,88 \\
\hline \multicolumn{2}{|r|}{ Jumlah } & 17 & 100 \\
\hline
\end{tabular}

Berdasarkan tabel 2 diketahui bahwa secara umum terdapat dua siswa (11,76\%) yang tingkat perilaku prososialnya berada pada kategori sangat tinggi dan sedang, terdapat sembilan siswa $(52,94 \%)$ yang tingkat perilaku prososialnya pada kategori tinggi, tiga siswa $(17,65 \%)$ yang memiliki tingkat perilaku prososial pada kategori rendah, serta satu siswa $(5,88 \%)$ dengan tingkat perilaku prososial yang sangat rendah. Hasil ini menggambarkan bahwa tingkat perilaku prososial siswa setelah diberikan movie therapy meningkat. Peningkatan itu didasarkan atas terjadinya perubahan kategorisasi perilaku prososial siswa 
di mana sebelum diberikan movie therapy tingkat perilaku prososial siswa berada pada kategori rendah, sedangkan setelah movie therapy diberikan maka tingkat perilaku prososial siswa meningkat menjadi kategori tinggi.

Untuk mengetahui apakah peningkatan tersebut bersifat signifikan maka dilakukan uji tanda (sign test). Kriteria penarikan kesimpulan uji tanda menggunakan nilai probabilitas sebear $0,05 \%$. Jika asyimp. sign $>0,05$, maka $\mathrm{H}_{0}$ diterima berarti movie therapy tidak efektif mengembangkan perilaku prososial siswa, dan jika asyimp. sign $<0,05$, maka $\mathrm{H}_{0}$ ditolak, berarti bahwa movie therapy efektif mengembangkan perilaku prososial siswa. ${ }^{32}$ Berikut merupakan hasil uji tanda.

Tabel 3. Output uji tanda dengan bantuan SPSS versi 20

Test Statistics ${ }^{\mathrm{a}}$

\begin{tabular}{lr}
\hline & Pretest - Posttest \\
\hline Exact Sig. (2-tailed) & $.000^{\mathrm{b}}$ \\
\hline
\end{tabular}

a. Sign Test

b. Binomial distribution used.

Berdasarkan tabel 3 diketahui bahwa nilai asyimp. sign sebesar 0,000<0,05. Hal ini berarti bahwa $\mathrm{H}_{0}$ yang berbunyi movie therapy tidak efektif mengembangkan perilaku prososial siswa dinyatakan ditolak. Dengan demikian dapat diketahui bahwa movie therapy efektif mengembangkan perilaku prososial siswa. Pada dasarnya movie therapy merupakan proses menggunakan film yang dibuat yang ditayangkan melalui layar besar atau televisi untuk maksud terapeutik. ${ }^{33}$ Pandangan lain mengemukakan bahwa movie therapy dirancang dengan menggunakan film atau gambar bergerak untuk menantang dan mengubah cara berpikir dan sistem kepercayaan irasional klien, dengan cara membantu klien mengubah pola pikirnya. ${ }^{34}$ Movie therapy adalah suatu teknik terapi yang melibatkan pemilihan yang cermat dan penugasan film agar klien menonton dengan tindak lanjut pengolahan

\footnotetext{
32 Singgih Santoso, Panduan Lengkap SPSS Versi 20, Edisi Revi (Jakarta: PT. Elex Media Komputindo, 2014).

33 Philippa Strong and George Lotter, "Reel Help for Real Life: Film Therapy and Beyond," HTS Teologiese Studies / Theological Studies 71, no. 3 (2015): 1-8, https://doi.org/10.4102/hts.v71i3.2878.

${ }^{34}$ Heewon Yang and Youngkhill Lee, "The Use of Single-Session Cinematherapy and Aggressive Behavioral Tendencies among Adopted Children — A Pilot Study," American Journal of Recreation Therapy, 2005, 1-10.
} 


\section{Dian R., Hengki S., Rezky P., Anna R., Sri Utami, dan Afiatin Nisa}

pengalaman mereka selama sesi terapi..$^{35}$ Movie therapy adalah pendekatan terapeutik yang mempersiapkan klien untuk menyaksikan dan menilai film berdasarkan interaksi karakter dengan yang lain, lingkungannya dan masalah pribadi, dengan cara mengembangkan penghubung untuk menyelesaikan terapeutik positif. ${ }^{36}$

Di lain pihak, perilaku prososial merupakan bentuk tingkah laku yang bersifat integral dalam kehidupan sosial manusia. ${ }^{37}$ Tidak hanya pada orang dewasa, perilaku prososial pula bisa ditampakkan oleh anak usia dini. Anak-anak yang menunjukkan keterampilan prososial yang kuat mampu mengelola tantangan sosial dan kompeten secara sosial. ${ }^{38}$ Di dalam movie therapy ditentukan bahwa sinema dalam bentuk gambar bergerak yang akan digunakan kepada orang yang dibantu/klien sebagai proses penyembuhan. ${ }^{39}$ Adapun gambar bergerak yang dimaksud dapat berupa film maupun video. Di balik sebuah film tersimpan banyak pesan yang ingin disampaikan kepada pencinta film itu sendiri. Pesan tersebut dapat berupa simbol-simbol, kata-kata, maupun perilaku yang mengandung makna tertentu. Hal inilah yang disebut dengan metafor. Dalam film, karakter dan tema adalah metafora potensial. Movie therapy bermaksud agar klien dapat mengamati metaforis adegan dalam film yang mirip dengan kehidupan mereka sendiri. Dengan melihat adegan film, klien akan dapat melihat diri sendiri dan pengalaman mereka pada adegan-adegan yang ada, dan secara teoretis, dengan bimbingan profesional, untuk mendapatkan wawasan yang lebih luas dan perspektif baru tentang bagaimana mengatasi hambatan nyata yang mencegah mereka dari kebahagiaan sejati dan perubahan. Movie therapy dapat digunakan kepada anak usia dini. Hal ini tidak lepas dari kenyataan bahwa media memiliki efek yang

35 Sharp, C., J.V. Smith, and A. Cole, "Cinematherapy: Metaphorically Promoting Therapeutic Change," Counselling Psychology Quarterly 15, no. 3 (2002): 269 - 276.

36 L. E. Tyson, L.H. Foster, and C. M. Jones, "The Process of Cinematherapy As A Therapeutic Intervention," Alabama Counseling Association Journal 26, no. 1 (2000): 35 - 41.

${ }^{37}$ Kristen Dunfield et al., "Examining the Diversity of Prosocial Behavior: Helping, Sharing, and Comforting in Infancy," Infancy 16, no. 3 (2011): 227-47, https://doi.org/10.1111/j.1532-7078.2010.00041.x.

38 Brendan F Andrade, Dillon T Browne, and Rosemary Tannock, "Prosocial Skills May Be Necessary for Better Peer Functioning in Children with Symptoms of Disruptive Behavior Disorders.," PeerJ 2, no. August 2015 (2014): 1-16, https://doi.org/10.7717/peerj.487.

${ }^{39} \mathrm{Ha}$ Gang Kim, "Effects of a Cinema Therapy-Based Group Reminiscence Program on Depression and Ego Integrity of Nursing Home Elders," Journal of Korean Academy of Psychiatric and Mental Health Nursing 23, no. 4 (2014): 233-41; Georgios K. Lampropoulos, Nikolaos Kazantzis, and Frank P. Deane, "Psychologists' Use of Motion Pictures in Clinical Practice.," Professional Psychology: Research and Practice 35, no. 5 (2004): 53541, https://doi.org/10.1037/0735-7028.35.5.535. 
penting sepanjang awal masa kanak-kanak.

Bahkan pada usia 3 tahun, anak-anak dengan mudah meniru pada tayangan tv, video, dan film. ${ }^{40}$ Memutarkan tayangan film pada anak melalui movie therapy bertujuan agar anak mampu mengambil dan mempelajari nilai-nilai prososial yang terdapat dalam film itu sendiri. Salah satu manfaat yang perlu diperhatikan dalam menonton film adalah anak akan mampu memperoleh pengalaman kognitif dan afektif. ${ }^{41}$ Hal ini tentunya lebih mudah dilakukan daripada harus membaca buku dan sebagainya. Memutarkan film kepada anakanak akan membuka wawasan anak dalam mengkaji suatu masalah berdasarkan pada sudut pandang tertentu. Pemutaran film yang diikuti dengan pembahasan film setelah anak-anak menonton mampu membuat anak untuk mengeluarkan penilaiannya terhadap apa yang telah ditonton.

Isi atau konten yang diputarkan dalam movie therapy perlu diperhatikan. Isi dari media memiliki peran yang vital dalam menilai efek media terhadap perubahan perilaku. ${ }^{42}$ Olehnya itu disarankan agar karakter dalam film yang diputar dan film yang ditayangkan pula harus diseleksi terlebih dahulu. Karakter atau tokoh dalam film menjadi titik fokus diskusi selama sesi terapi. ${ }^{43}$ Hal yang perlu didiskusikan selama sesi terapi setelah menonton film antara lain: ceritakan tentang karakter dalam film, apa yang karakter tersebut alami, apa yang menjadi permasalahan utama karakter yang ditonton, bagaimana cara karakter keluar dari masalahnya, adakah cara lain yang karakter gunakan untuk keluar dari masalah, apa hubungan klien dengan karakter yang ada dalam film, dan siapa yang anda suka atau tidak suka di dalam film.

Pertanyaan-pertanyaan tersebut dikeluarkan karena karakter dapat menjadi model

\footnotetext{
${ }^{40}$ Calvert, "Media and Early Development."

${ }^{41}$ Chuchai Smithikrai, Nathawat Longthong, and Chatwiboon Peijsel, "Effect of Using Movies to Enhance Personal Responsibility of University Students," Asian Social Science 11, no. 5 (2015): 1-9, https://doi.org/10.5539/ass.v11n5p1.

42 Sarah M. Coyne et al., "Pow! Boom! Kablam! Effects of Viewing Superhero Programs on Aggressive, Prosocial, and Defending Behaviors in Preschool Children," Journal of Abnormal Child Psychology, 2017, 1-13, https://doi.org/10.1007/s10802-016-0253-6.

43 Molaie and Abedin, "Effectiveness of Group Movie Therapy (GMT) on Reduction of Grief Experience Intensity in Bereaved Adolescent Girls."
} 


\section{Dian R., Hengki S., Rezky P., Anna R., Sri Utami, dan Afiatin Nisa}

untuk pemecahan masalah perilaku yang dialami oleh klien. ${ }^{44}$ Melalui tontonan itu, klien dapat mencapai kesadaran mengenai strategi koping alternatif tanpa perlu khawatir akan konsekuensi negatif yang mungkin timbul dalam hidupnya. Hal ini dikarenakan oleh strategi tersebut akan dibahas secara bersama mengenai kelebihan dan kekurangannya. Ada empat tahap dalam pelaksanaan movie therapy, yakni identifikasi, katarsis emosional, universalisasi, dan pemahaman baru.

Mekanisme internalisasi nilai dari film berlangsung sepanjang kegiatan menonton melalui transferensi, dan proses-proses kolekfit dari proyeksi, identifikasi dan introyeksi. Kemudian, movie therapy dilakukan dengan perhatian dan pembimbingan dalam menonton yang diikuti dengan diskusi mengenai kemungkinan film menyediakan katarsis emosi, pemrosesan dan penerimaan umpan balik, dan pada akhirnya pembelajaran baru. Hal ini pada gilirannya akan mempercepat akses dalam dimensi dan pemodelan yang lebih luas untuk menyesuaikan keterampilan yang dimiliki klien. Film yang diputar dalam movie therapy sarana alternatif untuk menciptakan perubahan dengan cara yang tidak mengancam, dan memberi klien kesempatan untuk menilai gagasan dan perilaku alternatif dengan aman. ${ }^{45}$ Dengan menggunakan film dalam situasi terapi, klien mampu menghubungkan secara emosional, kognitif, dan perilaku dengan karakter yang masalahnya ditampilkan dengan memiliki kesamaan dengan masalah yang dimilikinya. Tidak hanya menyediakan klien suatu kesempatan untuk memikirkan bahwa mereka tidak sendiri dalam menghadapi masalah, movie therapy membantu mereka untuk melihat bahwa orang lain memiliki masalah yang sama dengan mereka sehingga mampu memacu klien dalam berjuang untuk menyelesaikan masalahnya sendiri.

\section{Simpulan}

Melalui penelitian ini ditemukan bahwa movie therapy efektif dalam mengembangkan perilaku prososial pada anak usia dini. Movie therapy dapat digunakan oleh guru BK sebagai sarana untuk mengembangkan kompetensi sosial siswa di sekolah. Meskipun demikian, dalam mengupayakan pelaksanaan movie therapy tentunya dibutuhkan sarana dan prasarana

\footnotetext{
${ }^{44}$ Molaie and Abedin.

45 Yang and Lee, "The Use of Single-Session Cinematherapy and Aggressive Behavioral Tendencies among Adopted Children — A Pilot Study.”
} 
pendukung. Untuk itu, bagi kepala sekolah diharapkan mampu menyediakan sarana dan prasarana yang dibutuhkan dalam pelaksanaan movie therapy. Di samping itu, guru BK selaku pelaksana movie therapy diharapkan mampu cermat dalam memilih film atau video yang akan digunakan dalam melakukan movie therapy.

\section{Daftar Pustaka}

Andrade, Brendan F, Dillon T Browne, and Rosemary Tannock. "Prosocial Skills May Be Necessary for Better Peer Functioning in Children with Symptoms of Disruptive Behavior Disorders." PeerJ 2, no. August 2015 (2014): 1-16. https://doi.org/10.7717/peerj.487.

Briggs, R.D. "The Importance of Social Emotional Development in Early Childhood."Pediatrics for Parent 28 (2012): 10-16.

Brownell, Celia A. "Early Development of Prosocial Behavior: Current Perspectives."Infancy 18, no. 1 (2013): 1-9. https://doi.org/10.1111/infa.12004.

Calvert, Sarah L. "Media and Early Development." In Blackwell Handbook of Early Childhood Development, edited by Kathleen McCartney and Deborah Phillips, 508-30. UK: Blackwell Publishing, 2006. https://doi.org/10.1007/s13398-014-0173-7.2.

Cirelli, Laura K., Kathleen M. Einarson, and Laurel J. Trainor. "Interpersonal Synchrony Increases Prosocial Behavior in Infants." Developmental Science 17, no. 6 (2014): 1003-11. https://doi.org/10.1111/desc.12193.

Coyne, Sarah M., Laura Stockdale, Jennifer Ruh Linder, David A. Nelson, Kevin M. Collier, and Lee W. Essig. "Pow! Boom! Kablam! Effects of Viewing Superhero Programs on Aggressive, Prosocial, and Defending Behaviors in Preschool Children." Journal of Abnormal Child Psychology, 2017, 1-13. https://doi.org/10.1007/s10802-016- 0253-6.

Dunfield, Kristen, Valerie A. Kuhlmeier, Laura O'Connell, and Elizabeth Kelley. "Examining the Diversity of Prosocial Behavior: Helping, Sharing, and Comforting in Infancy." Infancy 16, no. 3 (2011): 227-47. https://doi.org/10.1111/j.1532- 7078.2010.00041.x.

Flook, Lisa, Simon B. Goldberg, Laura Pinger, and Richard J. Davidson. "Promoting Prosocial Behavior and Self-Regulatory Skills in Preschool Children through a Mindfulness-Based Kindness Curriculum." Developmental Psychology 51, no. 1 (2015): 44-51. https://doi.org/10.1037/a0038256.

Gentile, Douglas A., Craig A. Anderson, Shintaro Yukawa, Nobuko Ihori, Muniba Saleem, Lim Kam Ming, Akiko Shibuya, et al. "The Effects of Prosocial Video Games on Prosocial Behaviors: International Evidence From Correlational, Longitudinal, and Experimental Studies." Personality and Social Psychology Bulletin 35, no. 6 (2009): 752-63. https://doi.org/10.1177/0146167209333045. 
Gramaglia, Carla, Amalia Jona, Fredrica Imperatori, Eugenio Torre, and Patrizia Zeppegno. "Cinema in the Training of Psychiatry Residents: Focus on Helping Relationships.” BMC Medical Education 13, no. 1 (2013): 90. https://doi.org/10.1186/1472-6920-13-90.

Greitemeyer, Tobias, and Silvia Osswald. "Effects of Prosocial Video Games on Prosocial Behavior." Journal of Personality and Social Psychology 98, no. 2 (2010): 211-21. https://doi.org/10.1037/a0016997.

Guinote, Ana, Ioanna Cotzia, Sanpreet Sandhu, and Pramila Siwa. "Social Status Modulates Prosocial Behavior and Egalitarianism in Preschool Children and Adults." Proceedings of the National Academy of Sciences 112, no. 3 (2015): 731-36. https://doi.org/10.1073/pnas.1414550112.

Kärtner, Joscha, Heidi Keller, and Nandita Chaudhary. "Cognitive and Social Influences on Early Prosocial Behavior in Two Sociocultural Contexts." Developmental Psychology 46, no. 4 (2010): 905-14. https://doi.org/10.1037/a0019718.

Kim, Ha Gang. "Effects of a Cinema Therapy-Based Group Reminiscence Program on Depression and Ego Integrity of Nursing Home Elders." Journal of Korean Academy of Psychiatric and Mental Health Nursing 23, no. 4 (2014): 233-41.

Kirschner Sebastian, S., and Michael Tomasello. "Joint Music Making Promotes Prosocial Behavior in 4-Year-Old Children." Evolution and Human Behavior 31, no. 5 (2010): 354-64. https://doi.org/10.1016/j.evolhumbehav.2010.04.004.

Lampropoulos, Georgios K., Nikolaos Kazantzis, and Frank P. Deane. "Psychologists' Use of Motion Pictures in Clinical Practice." Professional Psychology: Research and Practice 35, no. 5 (2004): 535-41. https://doi.org/10.1037/0735-7028.35.5.535.

Layous, Kristin, S. Katherine Nelson, Eva Oberle, Kimberly A. Schonert-Reichl, and Sonja Lyubomirsky. "Kindness Counts: Prompting Prosocial Behavior in Preadolescents Boosts Peer Acceptance and Well-Being." PLOS ONE 7, no. 12 (2012): 7-9. https://doi.org/10.1371/journal.pone.0051380.

Li, Ya. "Nostalgia Promoting Pro-Social Behavior and Its Psychological Mechanism." Open Journal of Social Sciences 3, no. October (2015): 177-86.

Molaie, A., and AR Abedin. "Effectiveness of Group Movie Therapy (GMT) on Reduction of Grief Experience Intensity in Bereaved Adolescent Girls." Iranian Journal of Psychiatry and Behavioral Sciences 5, no. 1 (2011): 25-32. http://206.223.176.35/files/onlineJournals_2506408= molaei.pdf.

Nurjanah, E. "Pengaruh Media Film Terhadap Motivasi Belajar Dalam Pembelajaran Pendidikan Kewarganegaraan (PKn)." University of Education Indonesia, 2013.

Nurmalitasari, Femmi. "Perkembangan Sosial Emosi Pada Anak Usia Prasekolah." Buletin Psikologi, 2015. https://doi.org/10.22146/bpsi.10567.

Plummer, Deborah M. Helping Children to Improve Their Communication Skills: Therapeutic Activities for Teachers and Parents and Therapists. London \& Philadelphia: Jessica Kingsley Publishers, 2011. https://doi.org/10.1080/1034912X.2014.934022. 
Prayitno, and Erman Amti. Dasar-Dasar Bimbingan Dan Konseling. Edisi Revi. Jakarta: PT. Rineka Cipta, 2013.

Santoso, Singgih. Panduan Lengkap SPSS Versi 20. Edisi Revi. Jakarta: PT. Elex Media Komputindo, 2014.

Santrock, J.W. Child Development. Climate Change 2013 - The Physical Science Basis. 13th ed. New York: McGraw-Hill Companies, Inc., 2010. https://doi.org/10.1017/CBO9781107415324.004.

Schonert-Reichl, Kimberly A., Veronica Smith, Anat Zaidman-Zait, and Clyde Hertzman. "Promoting Children's Prosocial Behaviors in School: Impact of the 'Roots of Empathy' Program on the Social and Emotional Competence of School-Aged Children." School Mental Health 4, no. 1 (2012): 1-21. https://doi.org/10.1007/s12310-011-9064-7.

Schunk, D.H. Learning Theories An Educational Perspective Teori-Teori Pembelajaran: Perspektif Pendidikan. 6th ed. Yogyakarta: Pustaka Pelajar, 2012.

Shaffer, David R, and K. Kipp. Developmental Psychology: Childhood and Adolescence. 8 th ed.

Belmont, CA 94002-3098: Wadsworth, 2010.

Sharp, C., J.V. Smith, and A. Cole. "Cinematherapy: Metaphorically Promoting Therapeutic Change.” Counselling Psychology Quarterly 15, no. 3 (2002): 269 - 276.

Smithikrai, Chuchai, Nathawat Longthong, and Chatwiboon Peijsel. "Effect of Using Movies to Enhance Personal Responsibility of University Students." Asian Social Science 11, no. 5 (2015): 1-9. https://doi.org/10.5539/ass.v11n5p1.

Strong, Philippa, and George Lotter. "Reel Help for Real Life: Film Therapy and Beyond." HTS Teologiese Studies/Theological Studies 71, no. 3 (2015): 1-8. https://doi.org/10.4102/hts.v71i3.2878.

Suranata, Kadek, and Made Sulastri. "Masalah-Masalah Yang Dialami Anak Usia Dini Dan Implikasinya Bagi Pelaksanaan Bimbingan Dan Konseling Di Taman KanakKanak." Jurnal Pendidikan Dan Pengajaran XLIII, no. 11 (2010): 89-95.

Suyanto, S. Dasar-Dasar Pendidikan Anak Usia Dini. Yogyakarta: Hikayat Publishing, 2005.

Tasimi, Arber, and Liane Young. "Memories of Good Deeds Past: The Reinforcing Power of Prosocial Behavior in Children." Journal of Experimental Child Psychology 147 (2016): 159-66. https://doi.org/10.1016/j.jecp.2016.03.001.

Trianto. Film Sebagai Media Belajar. Yogyakarta: Graha Ilmu, 2013.

Tyson, L. E., L.H. Foster, and C. M. Jones. "The Process of Cinematherapy As A Therapeutic Intervention." Alabama Counseling Association Journal 26, no. 1 (2000): $35-41$.

Wright, Lisa A., and Rebecca B. McCathren. "Utilizing Social Stories to Increase Prosocial 
Behavior and Reduce Problem Behavior in Young Children with Autism." Child Development Research 2012 (2012): 1-13. https:/ / doi.org/10.1155/2012/357291.

Yang, Heewon, and Youngkhill Lee. "The Use of Single-Session Cinematherapy and Aggressive Behavioral Tendencies among Adopted Children A Pilot Study." American Journal of Recreation Therapy, 2005, 1-10.

Yazici, Esra, Fuat Ulus, Rabia Selvitop, Ahmet Yazici, and Nazan Aydin. "Use of Movies for Group Therapy of Psychiatric Inpatients: Theory and Practice.” International Journal of Group Psychotherapy 64, no. 2 (2014): 255-70.

Yusuf, A.Muri. Metode Penelitian: Kuantitatif, Kualitatif, Dan Penelitian Gabungan. Jakarta: Kencana Prenadamedia Group, 2014. 